\title{
Cholinesterase from the Liver of Diodon hystrix for Detection of Metal Ions
}

\author{
Noreen Nordin, Ronaldo Ron Cletus, Mohd Khalizan Sabullah*, Siti Aishah \\ Muhammad Khalidi, Rahmath Abdulla and Siti Aqlima Ahmad
}

Faculty Science and Natural Resources, Universiti Malaysia Sabah, 88400, Kota Kinabalu, Sabah, Malaysia Department of Biochemistry, Faculty of Biotechnology and Biomolecular Sciences, Universiti Putra Malaysia, 43400 Serdang, Selangor, Malaysia

\begin{abstract}
The discharge of industrial effluents into nearby water bodies affects the inhabitants including living organisms. The presence of foreign materials such as heavy metals can be a threat to the ecosystem as they are enormously carcinogenic even though in minute concentration. Hence, an economical and time-efficient preliminary screening test is crucial to be developed for the detection of heavy metals, prior to employment of high technology instruments. In this study, cholinesterase (ChE) from Sabah porcupine fish, Diodon hystrix was purified to test for its potential as an alternative biosensor in detecting metal ions. Few enzymatic parameters including specificity of substrate, temperature and $\mathrm{pH}$ were applied to determine its optimal enzymatic activity. ChE enzyme was found to be more sensitive towards the presence of substrate, butyrylthiocholine iodide (BTC), in contrast to acetylthiocholine iodide (ATC) and propionylthiocholine iodide (PTC) with the effective coefficient at 7193, 3680.15 and $2965.26 \mathrm{~V}_{\max } / \mathrm{K}_{\mathrm{m}}$, respectively. Moreover, the extracted ChE enzyme showed the optimum activity at $\mathrm{pH} 9$ of $0.1 \mathrm{M}$ Tris- $\mathrm{HCl}$ and at $25^{\circ} \mathrm{C}$ to $30^{\circ} \mathrm{C}$ range of temperature. When subjected to heavy metals, ChE enzyme was significantly

ARTICLE INFO

Article history:

Received: 10 February 2020

Accepted: 13 November 2020

Published: 31 December 2020

DOI: https://doi.org/10.47836/pjst.28.S2.09

E-mail addresses:

ryeennordin@yahoo.com (Noreen Nordin)

ronronaldo96@gmail.com (Ronaldo Ron Cletus)

khalizan@ums.edu.my (Mohd Khalizan Sabullah)

asyaaishah@yahoo.com (Siti Aishah Muhammad Khalidi)

rahmathabdulla@ums.edu.my (Rahmath Abdulla)

inhibited as the enzyme activity was reduced in the sequence of $\mathrm{Hg}>\mathrm{Ag}>\mathrm{Cr}>\mathrm{Cu}>\mathrm{Cd}>$ $\mathrm{Pb} \geq \mathrm{Zn}>$ As. As a conclusion, the partially purified $\mathrm{ChE}$ enzyme proved its sensitivity towards metal ion exposure and can be used as an alternative method in screening the level of contamination in the environment.

Keywords: Cholinesterase, diodon hystrix, heavy metals, $\mathrm{pH}$, substrates, temperature
\end{abstract}

aqlima@upm.edu.my (Siti Aqlima Ahmad)

* Corresponding author 


\section{INTRODUCTION}

Water covers around $71 \%$ of the Earth surface. Water is being utilised by all life forms in various industries including food manufacturing and leisure industries. Yet, the accessibility of excellent water sources is gradually worsened as it is becoming polluted over time (Ahmad et al., 2016a; Gonzalez et al., 2009). The incorporation of noxious wastes such as heavy metals and pesticides into the ecosystem, deriving from multiple agrarian and industrial activities can produce alarming effects (Fatima et al., 2014; Sabullah et al., 2014).

The heavy metals are naturally prevailed elements and no less fivefold larger relative to water molecules. Their toxicity corresponds to exposure level, types of chemical and dosage. Mercury, lead, arsenic and cadmium are among the pre-eminent important materials that could affect the community health (Gupta et al., 2015). Based on the United States Environmental Protection Agency (USEPA), toxicity of heavy metals is discerned as carcinogenic to humans.

A series of observations is implemented as precautionary steps in controlling and reducing contamination level (Wang et al., 2018). The presence of toxicants may cause negative health effects and death. Hence, the preliminary evaluation of water quality is crucial for utilisation in everyday life. Equipped with contemporary automation such as High-Performance Liquid Chromatography (HPLC) and Inductively Coupled Plasma (ICP) in quantifying toxicants level, these inventions are costly, time-consuming and require expertise for handling (Sabullah et al., 2015). Therefore, alternatively, biosensor using enzyme can be used as a preliminary screening to detect contaminants level semiquantitatively.

Cholinesterase $(\mathrm{ChE})$ is an esterase responsible for lyses of choline esters, most of which act as neurotransmitters in the nervous system. ChE involves in hydrolysing acetylcholine (Ach) into its constituents, acetic acid and choline (Ch) (Čolović et al., 2013). Certain compounds such as carbamates and organophosphates possess high affinity in inhibiting ChE activity (Fukuto, 1990; Johnson \& Moore, 2012). Other than that, the metal ions are competent in binding at either $\mathrm{ChE}$ active or allosteric sites, impeding its activity.

The inhibition of ChE activity permits the detection of toxicants. From the observation, this scenario can be exploited in detecting metal ions at varying concentrations. Moreover, the process can be minimised as no involvement of the experts is needed. The screening time could also be reduced in which only samples showing enzymatic inhibition are selected for the secondary screening. Thus, numerous researchers are opting in addressing future biosensor advancement in order to satisfy the needs of the emergent world despite many issues arisen in the development of biosensor.

The porcupine fish, Diodon hystrix which holds hundred spines on its body is selected in this project. $D$. hystrix exhibits a distinct defence mechanism when it senses athreat, this fish will inflate its body by taking water inside and deflating when it is no longer threatened. 
This fish' through its skin can produce toxic or poisonous substances. It is interesting as $D$. hystrix uses many ChE enzymes to properly function for its unique expertise. The objective of the present project was to extract and partially purify the ChE enzyme from the liver tissue of $D$. hystrix. Then, the substrate specificity, optimum temperature and $\mathrm{pH}$ of purified $\mathrm{ChE}$ were determined and the inhibitor effects on the $\mathrm{ChE}$ enzymatic activity were assessed.

\section{MATERIALS AND METHODS}

\section{Materials}

Five adult porcupine fish, Diodon hystrix sized 30-33.5 cm and weighing 800-1000g were obtained from the local Sabah wet market at Kota Kinabalu, Sabah.

\section{Sample Preparation}

The liver of Diodon hystrix was dissected out and weighed immediately. Using mortar and pestle for extraction, liver tissue was squeezed and subsequently transferred into a beaker containing sodium phosphate buffer $(0.1 \mathrm{M}, \mathrm{pH} 7)$ in a ratio of $1: 4(\mathrm{w} / \mathrm{v})$ in cold condition. The homogenisation was performed using Ultra-Turrax T-25 homogeniser in which 500 $\mu \mathrm{L}$ homogenate was stored at $-20^{\circ} \mathrm{C}$ for enzyme and protein assay. The centrifugation of homogenate was taken place at $10,000 \times g$ for 10 minutes at $4^{\circ} \mathrm{C}$ to eliminate the presence of cell debris. The supernatant was collected and stored at $-20^{\circ} \mathrm{C}$ for further purification.

\section{Ion Exchange Chromatography Purification}

The purification of ChE was performed using diethylaminoethanol (DEAE) matrix linked to Sepharose (Peterson \& Sober, 1956). A syringe (0.9 cm diameter, $6 \mathrm{~cm}$ height) was packed with matrix and let to settle until $3 \mathrm{~cm}$ bed height was obtained. The flow rate was calibrated at $0.2 \mathrm{~mL} / \mathrm{min}$. The column was washed with 5 batch volumes of washing buffer (25 mM sodium phosphate buffer, $\mathrm{pH} 7.5$ ) and then eluted with eluting buffer $(25 \mathrm{mM}$ sodium phosphate buffer, $\mathrm{pH} 7.5$ at various concentrations of $0.2 \mathrm{M}, 0.4 \mathrm{M}, 0.6 \mathrm{M}, 0.8 \mathrm{M}$ and $1.0 \mathrm{M} \mathrm{NaCl}$ ). The fractions were collected with a volume of $1 \mathrm{~mL}$ from washing to eluting stages. The column then washed with five batch volumes of washing buffer and stored in $20 \%$ ethanol at $4^{\circ} \mathrm{C}$.

\section{Cholinesterase Enzyme and Protein Assay}

The enzyme activity of ChE was assayed using modified Ellman method (Ellman et al., 1961). The reaction mixture was prepared containing $200 \mu \mathrm{L}$ of $0.1 \mathrm{M}$ sodium phosphate buffer, $\mathrm{pH}$ 7.5, $20 \mu \mathrm{L}$ of $0.067 \mathrm{mM}$ 5.5'-dithiobis-2-nitrobenzoic acid (DTNB) and $10 \mu \mathrm{L}$ of ChE sample. The mixture was loaded into 96 microplates well. The mixture was incubated 
for 15 minutes at room temperature before the addition of $20 \mu \mathrm{L}$ acetylthiocholine iodide (ATC) into the mixture. It was then incubated for additional 10 minutes before absorbance reading was recorded at $405 \mathrm{~nm}$ using multimode detector. The $\mathrm{ChE}$ sample was substituted with $0.1 \mathrm{M}$ sodium phosphate buffer, $\mathrm{pH} 7.5$ for the control test. The production of yellow colour signified ChE activity with extinction coefficient of $0.0136 \mu \mathrm{M}^{-1} \mathrm{~cm}^{-1}$. A unit of activity is defined as amount of substrate ( $\mu$ mole) hydrolysed by AChE per minute (U) with $0.0136 \mu \mathrm{M}^{-1} \mathrm{~cm}^{-1}$ extinction coefficient.

The protein assay was performed using Bradford method (Bradford, 1976). The determination of protein content was quantified using bovine serum albumin as a standard. The reaction mixture containing $200 \mu \mathrm{L}$ Bradford reagent and $20 \mu \mathrm{L} \mathrm{ChE} \mathrm{sample} \mathrm{was}$ loaded into the well and absorbance was recorded at $595 \mathrm{~nm}$ after 10 minutes incubation at room temperature.

\section{Optimal pH, Temperature and Substrate Specificity}

The determination of optimum $\mathrm{pH}$ was carried out using an overlapping buffer system; 0.1 $\mathrm{M}$ acetic acid ( $\mathrm{pH}$ ranged 3.0 to 5.5), sodium phosphate ( $\mathrm{pH}$ ranged 6.0 to 8.0) and Tris$\mathrm{HCl}$ buffers ( $\mathrm{pH}$ ranged 7.0 to 9.0). The optimal temperature was determined by incubation at 6 different temperature ranged from $15^{\circ} \mathrm{C}$ to $45^{\circ} \mathrm{C}$, followed by addition of substrate.

The substrate specificity test was performed using three substrates, acetylthiocholine iodide (ATC), butyrylthiocholine iodide (BTC) and propionylthiocholine iodide (PTC). The assay was performed separately for each substrate with concentration from $0 \mathrm{mM}$, $0.1 \mathrm{mM}, 0.5 \mathrm{mM}, 1.0 \mathrm{mM}, 1,5 \mathrm{mM}, 2.0 \mathrm{mM}$ and $2.5 \mathrm{mM}$. The determination of preferred substrate was calculated using Michaelis-Menten kinetics (maximal velocity, $\mathrm{V}_{\max }$ and biomolecular constant, $\mathrm{K}_{\mathrm{m}}$ ) using GraphPad PRISM version 5 software.

\section{Metal Ions Inhibition Study}

The eight types of heavy metals were used which were copper $\left(\mathrm{Cu}^{2+}\right)$, silver $\left(\mathrm{Ag}^{2+}\right)$, cadmium $\left(\mathrm{Cd}^{2+}\right)$, arsenic $\left(\mathrm{As}^{5+}\right)$, chromium $\left(\mathrm{Cr}^{5+}\right)$, mercury $\left(\mathrm{Hg}^{2+}\right)$, lead $\left(\mathrm{Pb}^{2+}\right)$ and zinc $\left(\mathrm{Zn}^{2+}\right)$ at concentration of $5 \mathrm{mg} / \mathrm{L}$. The assay was prepared containing $150 \mu \mathrm{L} 0.1 \mathrm{M}$ Tris-HCl buffer, $\mathrm{pH} 9,50 \mu \mathrm{L} 5 \mathrm{mg} / \mathrm{L}$ metal ions, $20 \mu \mathrm{L} 0.067 \mathrm{mM}$ DTNB and $10 \mu \mathrm{L} \mathrm{ChE}$ enzyme. The reaction mixture was loaded into the well and incubated for 15 minutes at room temperature. BTC with a volume of $20 \mu \mathrm{L}$ was added into the reaction mixture and incubated for 10 minutes at room temperature. The absorbance was recorded at $405 \mathrm{~nm}$ and the control test was conducted by replacing heavy metals with distilled water.

\section{Statistical Analysis}

All data obtained were in the form of means \pm standard deviation (SE) and analysed using GraphP ad Prism version 5.0. The one-way analysis of variance (ANOVA) with post hoc 
analysis by Tukey's test was employed to calculate the comparison between two or more groups of data.

\section{RESULTS AND DISCUSSION}

\section{Purification Profile}

The purification of ChE from Diodon hystrix was successfully performed using DEAESepharose matrix with total of 26 fractions. The highest ChE activity was in fraction of 19 to 26. The fractions 1 to 16 showed low ChE activity indicated no overloading of enzyme inside the column with fraction 27 as a control. Figure 1 shows ChE from liver tissue of $D$. hystrix was purified at 3.65 -fold with $45.3 \%$ recovery. The low recovery may be due to ligand leakage, absorption of non-specific protein and interaction on the surfaces such as unsuitable temperature and $\mathrm{pH}$ (Efremova et al., 2001). Besides, low total ChE recovery may be due to the existence of thermal energy in the system.

The partial purification procedure was summarised in Table 1. The fold was denoted as specific activity after fractionation divides with crude homogenate and applied to estimate

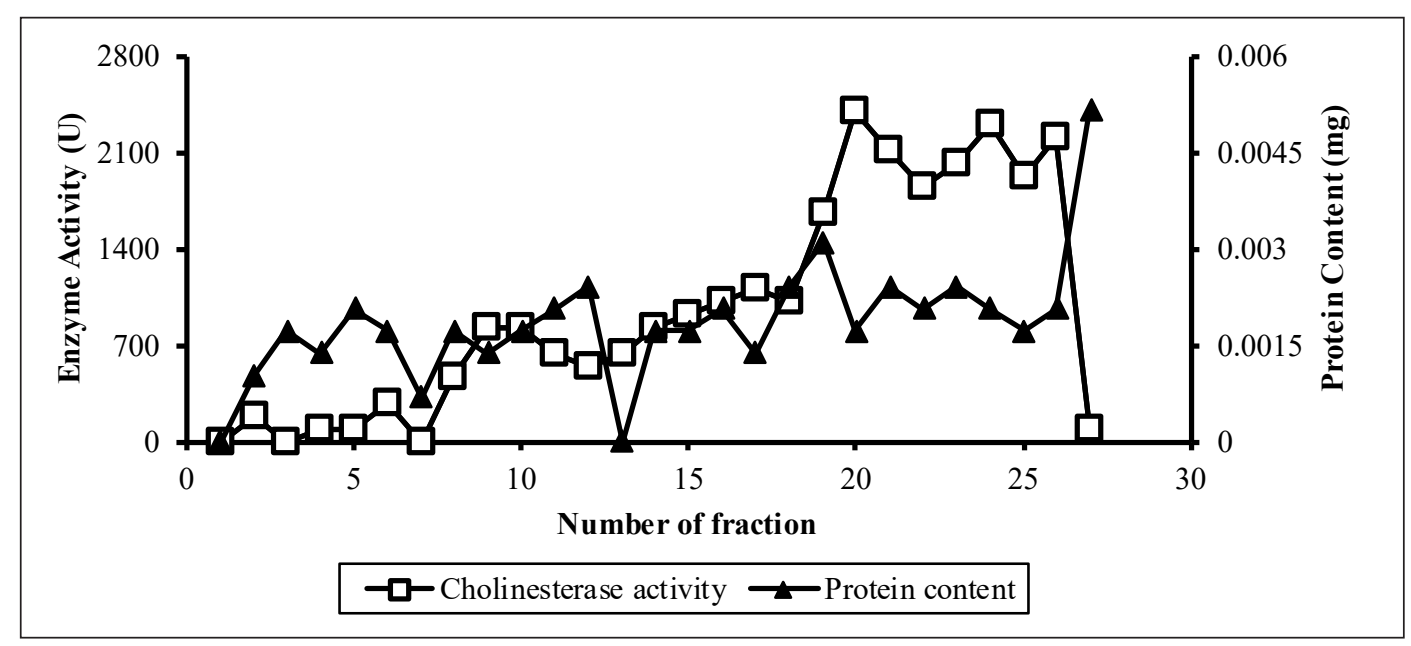

Figure 1. The purification profile of ChE from liver extract of $D$. hystrix using DEAE matrix

Table 1

The comparison of extraction and purification methods of D. hystrix ChE, in which total ChE activity was expressed in U for each purification step

\begin{tabular}{cccccc}
\hline & \multicolumn{2}{c}{ Total recovery } & Specific \\
\cline { 2 - 5 } & $\begin{array}{c}\text { Total protein } \\
\text { (mg) }\end{array}$ & $\begin{array}{c}\text { Total ChE } \\
\text { activity } \\
\text { (U) }\end{array}$ & $\begin{array}{c}\text { activity (U/ } \\
\mathbf{m g})\end{array}$ & $\begin{array}{c}\text { Purification } \\
\text { folds } \\
\text { (x) }\end{array}$ & $\begin{array}{c}\text { Yield } \\
\text { (\%) }\end{array}$ \\
\hline Crude homogenate & 8.76 & 7659.375 & 871.91 & 1 & 100 \\
Supernatant & 3.97 & 5269.669 & 1326.70 & 1.52 & 68.8 \\
Purified & 0.75 & 2389.71 & 3186.28 & 3.65 & 45.34 \\
\hline
\end{tabular}


the times of enzyme has purified. Meanwhile, yield was determined using the homogenate as a reference point with $100 \%$ retained enzymatic activity during purification process. From Table 1, it can be noted that the decrement of the number of protein and ChE activity through each step. The removal of unwanted protein such as insoluble fats and inorganic during the elution stage has increased the specific activity of the desired protein.

The low yield percentage indicated the denaturation of purified enzyme during purification process. The partially purified enzyme may denature due to inappropriate surrounding temperature and $\mathrm{pH}$ used along the process. Temperature can cause the enzyme to be more active and produce high kinetic energy to facilitate more collision which can alter the structure of enzyme. For $\mathrm{pH}$, the enzyme reacts with hydrogen ion that binds to the active site, hence changing the shape of the enzyme (Efremova et al., 2001; Robinson, 2015).

\section{Substrate Specificity}

The cholinesterase (ChE) works in hydrolysis of the predominant choline ester, acetylcholine, Ach. However, Ach was not being utilised as a substrate in this study as the liver could contain acetylcholinesterase (AChE), butyrylcholinesterase (BuChE) and propionylcholinesterase (PuChE) (Askar et al., 2011; Garcia-Aylion et al., 2012). Lockridge (2015) stated that BuChE and PuChE were abundant in livers but differed in their functions.

As can be seen in Figure 2, the prompt increase on the steepness of the BTC line was noted, indicating the sensitivity of the purified enzyme towards BTC as compared to the other substrates. However, PTC showed high enzymatic activity indicating the affinity of both synthetic substrates towards the purified ChE enzyme. To double confirm, the kinetic parameters of purified enzyme on substrates were determined using GraphPad Prism software.

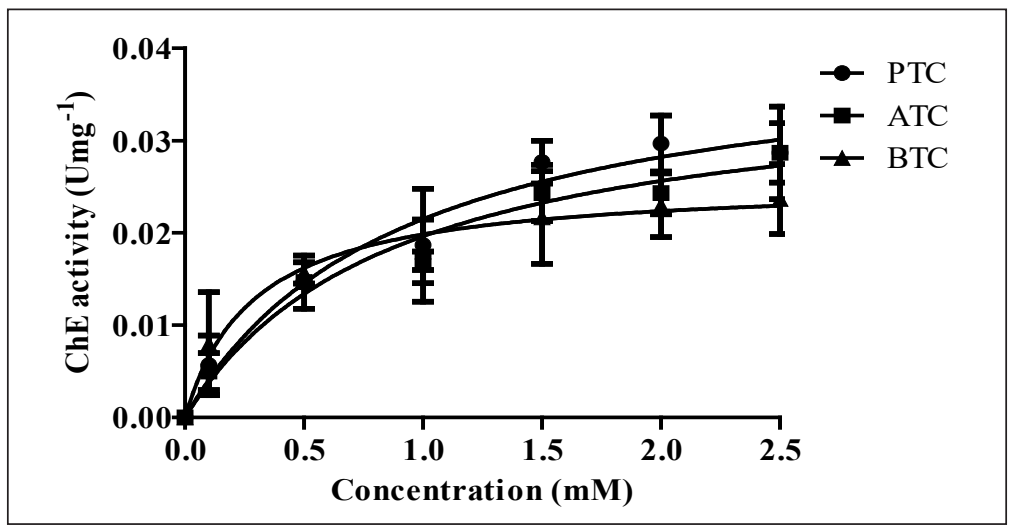

Figure 2. Michaelis-Menten plot of D. hystrix ChE incubated in three different synthetic substrates; Acetylthiocholine iodide (ATC), butyrylthiocholine iodide (BTC) and propionylthiocholine iodide (PTC) at concentration of 0 to $2.5 \mathrm{M}$ 
Based on Table 2, the value of $\mathrm{K}_{\mathrm{m}}$ for BTC, $0.2909 \mathrm{mM}$ was lower than ATC and PTC. The highest $\mathrm{V}_{\max }$ value was noted by PTC which was $3355.56 \mathrm{Umg}^{-1}$, followed by ATC (3054.22 $\left.\mathrm{Umg}^{-1}\right)$ and BTC (2092.44 $\left.\mathrm{Umg}^{-1}\right)$. The data obtained was in line with Figure 2. The preferable synthetic substrate of the enzyme was determined based on the catalytic efficiency $\left(\mathrm{V}_{\max } / \mathrm{K}_{\mathrm{m}}\right)$. The BTC was demonstrated as the preferable synthetic substrate with the highest ratio of $7193 \mathrm{U} \mathrm{mg}^{-1} \mathrm{mM}^{-1}$ as compared to the other two substrates. The result obtained was in line with the previous studies conducted using BTC as a specific substrate for the purified ChE from liver tissue of Puntius javanicus, Anabas testudineus and Clarias gariepinus (Ahmad et al., 2016b; Padrillah et al., 2017; Sabullah et al., 2014).

\section{Table 2}

The comparison of $K_{m}$ and $V_{\max }$ of synthetic substrates; acetylthiocholine iodide (ATC), butyrylthiocholine iodide (BTC) and propionylthiocholine iodide (PTC) using GraphPad Prism software

\begin{tabular}{cccc}
\hline & \multicolumn{2}{c}{ Mean point $\mathbf{( 9 5} \%$ confidence intervals) } \\
\cline { 2 - 4 } & ATC & BTC & PTC \\
\hline $\mathbf{V}_{\max }(\mathbf{U} / \mathbf{m g})$ & 3054.22 & 2092.44 & 3355.56 \\
$\mathbf{K}_{\mathrm{m}}(\mathbf{m} \mathbf{M})$ & 1.030 & 0.2909 & 0.9118 \\
Catalytic efficiencies $\left(\mathbf{V}_{\max } / \mathbf{K}_{\mathrm{m}}\right)$ & 2965.26 & 7193 & 3680.15 \\
\hline
\end{tabular}

\section{pH Profile}

The $\mathrm{pH}$ profile of the purified enzyme was assessed using three buffer types; acetic acid, sodium phosphate and Tris-HCl buffer. An overlapping buffer system was utilized to cancel the effects of other buffers on the enzymatic activity.

Figure 3 presents the highest $\mathrm{pH}$ condition of $\mathrm{ChE}$ activity was at $\mathrm{pH} 9$ (the highest studied) in $0.1 \mathrm{M}$ Tris- $\mathrm{HCl}$ buffer. The $\mathrm{pH}$ can alter the hydrogen and ionic bonding of

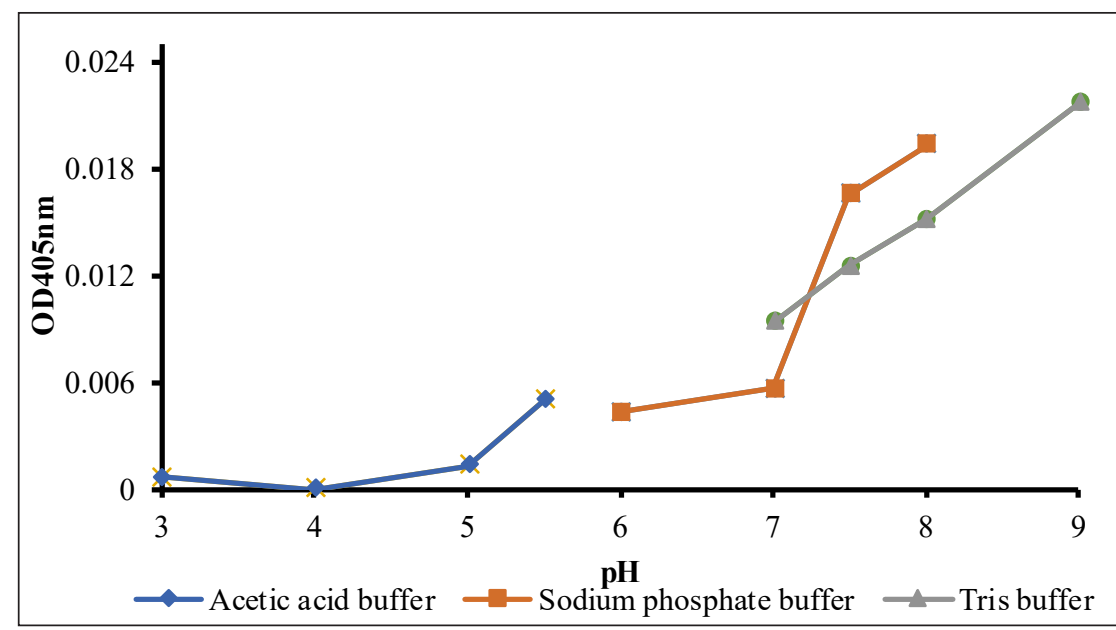

Figure 3. Optimization of $\mathrm{pH}$ for D.hystrix $\mathrm{ChE}$ activity. Data presented in absorbance value at wavelength of $405 \mathrm{~nm}$ (Final reading - initial reading) 
enzyme and stop the enzyme-substrate complex formation (Reece et al., 2011). At low $\mathrm{pH}$, the presence of excessive hydrogen ion leads to protonation of the imidazole group of histidine at catalytic triad of enzyme, and thus resulting in the loss of catalytic properties of enzyme (Masson et al., 2002; Masson \& Lockridge, 2010). At high pH, the alteration of charge of substrate binds to the enzyme causes no enzyme-substrate complex formation. The previous studies on the ChE activity of Lates calcarifer, Clarias gariepinus and Monopterus albus were also conducted using Tris-HCl buffer system which signified that ChE enzyme could work efficiently in the alkaline environment (Fadzil et al., 2018; Hayat et al., 2015, 2017; Khalidi et al., 2019; Sabullah et al., 2019).

\section{Temperature Profile}

The optimisation of the purified enzyme was conducted in different incubation temperatures as shown in Figure 4. The bell-shaped curve showed the optimum temperature of $D$. hystrix $\mathrm{ChE}$ at the range of $25^{\circ} \mathrm{C}$ to $30^{\circ} \mathrm{C}$. At optimal temperature, more enzyme-substrate complexes are formed which lead to an elevated number of products produces. Basically, the activity of the purified $\mathrm{ChE}$ was retarded at the temperature lower than $25^{\circ} \mathrm{C}$, as it did not have sufficient kinetic energy to facilitate the number of effective collisions between enzyme and substrate per unit time. High temperature may denature the enzyme and inactivates the active site. At extreme temperature, the thermal energy can cause more vibration until high enough to alter the bonds supporting the three-dimensions (3D) configuration of the enzyme and lowered the enzymatic activity (Bernabei et al., 1993; Fairbrother et al., 1991; Reece et al., 2011).

Fish was categorised as cold-blooded organisms, hence warmer temperature, beyond $30^{\circ} \mathrm{C}$ may denature or inactivate $\mathrm{ChE}$ (Sabullah et al., 2014). Almost all published studies on bioassay using liver $\mathrm{ChE}$ source from various animal types were carried out at temperature

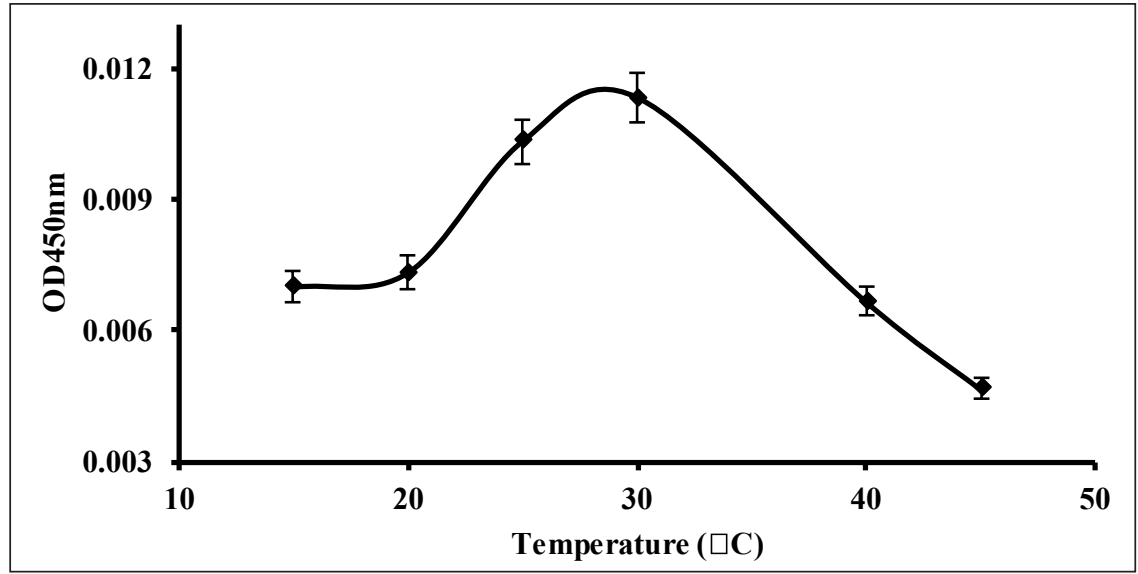

Figure 4. Optimization of temperature profile for D. hystrix $\mathrm{ChE}$ activity. Data presented in absorbance value at wavelength of $405 \mathrm{~nm}$ (Final reading - initial reading) 
range of 25 to $30^{\circ} \mathrm{C}$ (Askar et al., 2011; Sabullah et al., 2014; Sanchez-Hernandez et al., 2011).

\section{Inhibition Study}

The effectiveness of bioassay for purified ChE was determined by inhibition study of toxicants. The purified $\mathrm{ChE}$ was exposed with incubation of eight metal ions with final concentration of $5 \mathrm{mg} / \mathrm{L}$. From Figure 5, all metal ions were significantly inhibited the purified ChE by lowering the activity to $63.42,92.68,80.56,70.73,75.37,2.44,85.36$ and $87.05 \%$ for $\mathrm{Ag}^{(2+)}, \mathrm{As}^{(5+)}, \mathrm{Cd}^{(2+)}, \mathrm{Cr}^{(6+)}, \mathrm{Cu}^{(2+)}, \mathrm{Hg}^{(2+)}, \mathrm{Pb}^{(2+)}$ an $\mathrm{Zn}^{(2+)}$, respectively. Mercury $\left(\mathrm{Hg}^{2+}\right)$ showed the highest inhibition of $\mathrm{ChE}$ activity, followed by other four metal ions, but the inhibition did not exceed $50 \%$ activity. The toxicity level was assigned in decreasing order from $\mathrm{Hg}^{2+}>\mathrm{Ag}^{2+}>\mathrm{Cr}^{6+}>\mathrm{Cu}^{2+}>\mathrm{Cd}^{2+}>\mathrm{Pb}^{2+} \geq \mathrm{Zn}^{2+}>\mathrm{As}^{5+}$.

Heavy metals involved in the formation of enzyme-substrate complex, although they can bind to enzyme active or allosteric sites and disrupt the formation. The binding of metal ions initiated reaction with functional hydroxyl and sulfhydryl groups, which eventually changes the shape and stops the substrates binding (Frasco et al., 2007; Glusker et al., 1999). The amino acids produce protein attraction on the presence of metal ions. The cation pull from imidazole group of histidine relates to attraction of free heavy metals and nitrogenous substrates (Dvir et al., 2010; Ma \& Dougherty, 1997; Sussman \& Silman, 1992).

The researches done by Frasco et al. (2007) and Wang et al. (2009) stated that among all metal ions, mercury and copper were the potent inhibitors for $\mathrm{ChE}$, which coincided

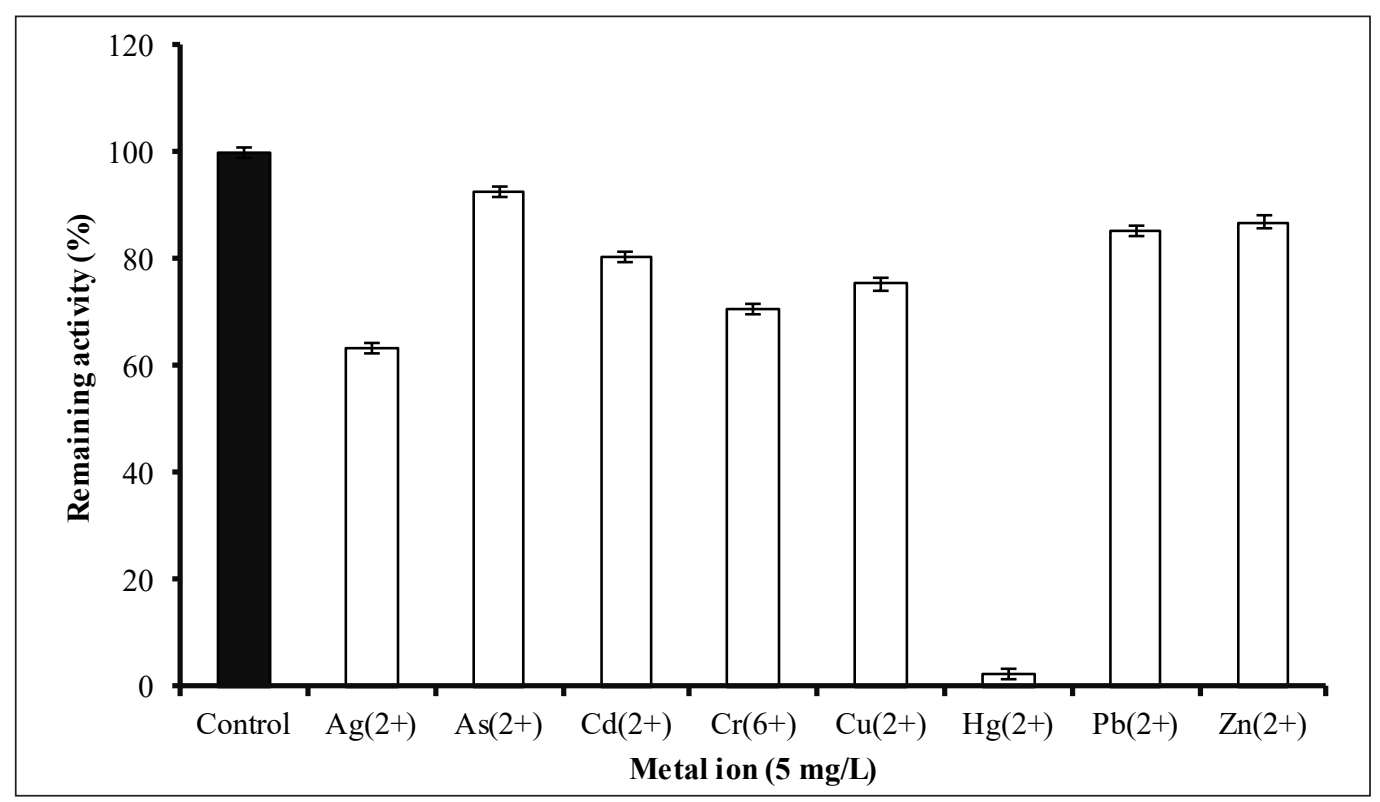

Figure 5. The percentage remaining activity of $D$. hystrix $\mathrm{ChE}$ after incubated in $5 \mathrm{mg} / \mathrm{L}$ of eight heavy metals. The alphabet denotes as statistically significant differences between each metal ion $(\mathrm{p}<0.05)$ 
with the finding in this study. Ariöz \& Wittung-Stafshede (2018) specified that the classic structural of transition metals like $\mathrm{Cu}$ permitted illustration on the binding potency of metal ions in inhibiting the $\mathrm{ChE}$ activity. Numerous studies conducted using fishes, for example Lates calcarifer, Puntius javanicus, Anabas testudineus and Clarias gariepinus displayed high $\mathrm{Hg}$ inhibition towards ChE activity (Ahmad et al., 2016b; Hayat et al., 2017; Padrillah et al., 2017; Sabullah et al., 2014). Study by Aidil et al. (2013) demonstrated the sensitivity of AChE of Pangasius hypophthalmus towards metal ions exposure such as $\mathrm{Ag}$, $\mathrm{Hg}, \mathrm{Cd}, \mathrm{Cu}, \mathrm{Zn}, \mathrm{Cr}$ and $\mathrm{Pb}$. The inhibition of these metal ions displayed the exponential decay type curve and its $\mathrm{IC}_{50}$ values were equal and lower in comparison to the existing biosensor assays like papain, immobilised urease, bromelain, Microtox ${ }^{\mathrm{TM}}$, Daphnia magna and rainbow trout. This study provides insight on the capability of ChE of D. hystrix in the detection of contaminants.

\section{CONCLUSION}

The cholinesterase (ChE) enzyme from liver tissue of $D$. hystrix was successfully purified using ion-exchange chromatography using DEAE-Sepharose as the matrix. The enzymatic parameters of $\mathrm{ChE}$ were determined, in which the enzyme worked at optimal rate in condition of $\mathrm{pH} 9,0.1 \mathrm{M}$ Tris- $\mathrm{HCl}$ buffer at temperature range of $25^{\circ} \mathrm{C}$ to $30^{\circ} \mathrm{C}$, alongside with the presence of BTC as the synthetic substrate. The inhibition study concluded that D. hystrix ChE was sensitive towards a few metal ions, especially towards $\mathrm{Hg}^{2+}$. Therefore, ChE of $D$. hystrix provides a promising alternative source for biorceptor to substitute the current $\mathrm{ChE}$ source in the market. It is recommended to explore the potential of purified D. hystrix ChE in detecting other pollutants like detergents, drug, dyes or pesticides.

\section{ACKNOWLEDGEMENTS}

The project was supported by Universiti Malaysia Sabah (UMS) under UMSGreat Grant No. GUG-0376-1/2019.

\section{REFERENCES}

Ahmad, S. A., Sabullah, M. K., Shamaan, N. A., Shukor, M. Y., Jirangon, H., Khalid, A. \& Syed, M. A. (2016a). Evaluation of acetylcholinesterase source from fish, for detection of carbamate. Journal of Environmental Biology, 37(4), 479-484.

Ahmad, S. A., Wong, Y. F., Shukor, M. Y., Sabullah, M. K., Yasid, N. A., Hayat, N. M., ... \& Syed, M. A. (2016b). An alternative bioassay using Anabas testudineus (Climbing perch) cholinesterase for metal ions detection. International Food Research Journal, 23(4), 1446-1452.

Aidil, M. S., Sabullah, M. K., Halmi, M. I. E., Sulaiman, R., Shukor, M. S., Shukor, M. Y., ... \& Syahir, A. (2013). Assay for heavy metals using an inhibitive assay based on the acetylcholinesterase from Pangasius hypophthalmus (Sauvage, 1878). Fresenius Environmental Bulletin, 22(12), 3572-3576. 
Ariöz, C. \& Wittung-Stafshede, P. (2018). Folding of copper proteins: Role of the metal?. Quarterly Reviews of Biophysics, 51, 1-39. doi:10.1017/s0033583518000021

Askar, K. A., Kudi, A. C. \& Moody, A. J. (2011). Comparative analysis of cholinesterase activities in food animals using modified Ellman and Michel assays. Canadian Journal of Veterinary Research, 75(4), $261-270$.

Bernabei, M., Chiavarini, S., Cremisini, C. \& Palleschi, G. (1993). Anticholinesterase activity measurement by a choline biosensor: Application in water analysis. Biosensors and Bioelectronics, 8(5), 265-271. doi:10.1016/0956-5663(93)80014-g

Bradford, M. M. (1976). Rapid and sensitive method for the quantitation of microgram quantities of protein utilizing the principle of protein-dye binding. Analytical Biochemistry, 72(1-2), 248-254. doi:10.1016/0003-2697(76)90527-3

Čolović, M. B., Krstić, D. Z., Lazarević-Pašti, T. D., Bondžić, A. M. \& Vasić, V. M. (2013). Acetylcholinesterase inhibitors: Pharmacology and toxicology. Current Neuropharmacol, 11(3), 315335. doi:10.2174/1570159X11311030006

Dvir, H., Silman, I., Harel, M., Rosenberry, T. L. \& Sussman, J. L. (2010). Acetylcholinesterase: From 3D structure to function. Chemico-Biological Interactions, 187(1-3), 10-22. doi:10.1016/j.cbi.2010.01.042

Efremova, N. V., Sheth, S. R. \& Leckband, D. E. (2001). Protein-induced changes in poly (ethylene glycol) brushes: Molecular weight and temperature dependence. Langmuir, 17(24), 7628-7636. doi:10.1021/ la010405c

Ellman, G. L., Courtney, K. D., Andres, J. V. \& Featherstone, R. M. (1961). A new and rapid colorimetric determination of acetylcholinesterase activity. Biochemical Pharmacology, 7(2), 88- 95. doi:10.1016/00062952(61)90145-9

Fadzil, N. I., Ahmad, S. A., Yasid, N. A., Sabullah, M. K., Daud, H. M., Khalid, A., ... \& Shukor, M. Y. (2017). Characterisation of cholinesterase and histopathological features of brain of Clarias gariepinus following exposure to cadmium. Journal of Environmental Biology, 40(2), 133-142. doi: 10.22438/ $\mathrm{jeb} / 40 / 2 / \mathrm{MRN}-815$

Fairbrother, A., Marden, B. T., Bennett, J. K. \& Hopper, M. J. (1991). Cholinesterase-inhibiting insecticides: Their impact on wildlife and the environment. In P. Mineau (Ed.), Methods used in determination of cholinesterase activity (pp. 35-710). New York: Elsevier. doi:10.1016/0300-483X(92)90129-3

Fatima, M., Usmani, N., Mobarak, Hossain, M., Siddiqui, M. F., Zafeer, M. F., Firdaus, F. \& Ahmad, S. (2014). Assessment of genotoxic induction and deterioration of fish quality I commercial species due to heavymetal exposure in an urban reservoir. Archives of Environmental Contamination and Toxicology, 67(2), 203-213. doi:10.1007/s00244-014-0024-8

Frasco, M. F. Colletier, J. P. \& Weik, M. (2007). Mechanisms of cholinesterase inhibition by inorganic mercury. The FEBS Journal, 274(7), 1849-1861. doi:10.1111/j.1742-4658.2007.05732.x

Fukuto, T. R. (1990). Mechanism of action of organophosphorus and carbamate insecticides. Environmental Health Perspectives, 87, 245-254. doi: 10.1289/ehp.9087245 
García-Ayllón, M. S., Small, D. H., Avila, J. \& Sáezvalero, J. (2011). Revisiting the role of acetylcholinesterase in Alzheimer's disease: Cross-talk with P-tau and B-amyloid. Frontiers in Molecular Neuroscience, 4(22), 1-9. doi: 10.3389/fnmol.2011.00022

Glusker, J. P., Katz, A. K. \& Bock, C. W. (1999). Metal ions in biological systems. The Rigaku Journal, 16(2), 381-412. doi:10.1201/9781482289893

Gonzalez, C., Greenwood, R. \& Quevauviller, P. (2009). Rapid chemical and biological techniques for water monitoring. Chichester, England: Wiley. doi:10.1002/9780470745427

Gupta, V. K., Singh, S., Agrawal, A. Siddiqi, N. J. \& Sharma, B. (2015). Phytochemicals mediated remediation of neurotoxicity induced by heavy metals. Biochemistry Research International, 2015, 1-9. doi:10.1155/2015/534769

Hayat, N. M., Ahmad, S. A., Shamaan, N. A., Sabullah, M. K., Shukor, M. Y., Syed, M. A., ... \& Dahalan, F. A. (2017). Characterisation of cholinesterase from kidney tissue of Asian Seabass (Lates calcarifer) and its inhibition in presence of metal ions. Journal of Environmental Biology, 38(3), 383-388. doi:10.22438/ jeb/38/3/MRN-987

Hayat, N. M., Shamaan, N. A., Shukor, M. Y., Sabullah, M. K., Syed, M. A., Khalid, A., .. \& Ahmad, S. A. (2015). Cholinesterase-based biosensor using Lates calcarifer (Asian seabrass) brain for detection of heavy metals. Journal of Chemical and Pharmaceutical Sciences, 8(2), 376-381.

Johnson, G. \& Moore, S. W. (2012). The carboxylesterase/cholinesterase gene family in invertebrate deuterostomes. Comparative Biochemistry and Physiology Part D: Genomics and Proteomics, 7(2), 83-93. doi:10.1016/j.cbd.2011.11.003

Khalidi, M. S. A., Sabullah, M. K., Sani, S. A., Ahmad, S. A., Shukor, M. Y., Jaafar, I. N. M. \& Gunasekaran, B. (2019). Acetylcholinesterase from the brain of Monopterus albus as detection of metal ions. Journal of Physics: Conference Series, 1358, 1-11. doi:10.1088/1742-6596/1358/1/012028

Lockridge, O. (2015). Review of human butyrylcholinesterase structure, function, genetic variants, history of use in the clinic, and potential therapeutic uses. Pharmacology and Therapeutics, 148, 34-46. doi:10.1016/j. pharmthera.2014.11.011

Ma, J. C., \& Dougherty, D. A. (1997). The cation- $\pi$ interaction. Chemical Reviews, 97(5), 1303-1324. doi:10.1021/cr9603744

Masson, P. \& Lockridge, O. (2010). Butyrylcholinesterase for protection from organophosphorus poisons; catalytic complexities and hysteretic behaviours. Archives of Biochemistry and Biophysics, 494(2), 107120. doi:10.1016/j.abb.2009.12.005

Masson, P., Schopfer, L. M., Bartels, C. F., Froment, M. T., Ribes, F., Nachon, F., \& Lockridge, O. (2002). Substrate activation in acetylcholinesterase induced by low $\mathrm{pH}$ or mutation in the $\pi$-cation subsite. Biochimica et Biophysica Acta (BBA)-Protein Structure and Molecular Enzymology, 1594(2), 313-324. doi:10.1016/s0167-4838(01)00323-5

Padrillah, S. N., Ahmad, S. A., Yasid, N. A., Sabullah, M. K., Daud, H. M., Khalid, A. \& Shukor, M. Y. (2017). Toxic effects of copper on liver and cholinesterase of Clarias gariepinus. Environmental Science and Pollution Research, 24(28), 22510-22523. doi:10.1007/s11356-017-9923-3 
Peterson, E. A. \& Sober, H. A. (1956). Chromatography of Proteins. I. Cellulose ion exchange adsorbents. Journal of the American Chemical Society, 78(4), 751-755. doi:10.1021/ja01585a016

Reece, J. B., Urry, L. A., Cain, M. L., Wasserman, S. A., Minorsky, P. V. \& Jackson, R. B. (2011). Campbell biology ninth edition (Book 9). California, USA: Benjamin Cummings.

Robinson, P. K. (2015). Enzymes: Principles and biotechnological applications. Essays in Biochemistry, 59(November), 1-41. doi:10.1042/bse0590001

Sabullah, M. K., Shukor, M. Y., Shamaan, N. A., Khalid, A., Gansau, A. J., Sulaiman, M. R., ... \& Ahmad, S. A. (2015). Purification and anticholinesterase sensitivity of cholinesterase extracted from liver tissue of Puntius javanicus. International Journal of Agriculture \& Biology, 17(5), 1025-1030. doi:10.17957/ ijab/15.0012

Sabullah, M. K., Khalidi, M. S. A., Wahid, A. D. N., Sani, A. S., Abdulla, R., Faik, M. A. A., ... \& Shukor, M. Y. (2019). Assessment of Monopterus albus liver as a source of cholinesterase for the detection of heavy metals. Journal of Physics: Conference Series, 1358, 1-9. doi:10.1088/1742-6596/1358/1/012029

Sabullah, M. K., Sulaiman, M. R., Shukor, M. Y. A., Syed, M. A., Shamaan, N. A., Khalid, A. \& Ahmad, S. A. (2014). The assessment of cholinesterase from the liver of Puntius javanicus as detection of metal ions. The Scientific World Journal, 2014, 1-9. doi:10.1155/2014/571094

Sussman, J. L. \& Silman, I. (1992) Acetylcholinesterase: Structure and use as a model for specific cation-protein interaction. Current Opinion in Structural Biology, 2(5), 721-729. doi:10.1016/0959-440x(92)90207-n

Wang, L., Zhang, F. Y., Pilot, E., Yu, J., Nie, C. J., Holdaway, J., ... \& Krafft, T. (2018). Taking action on air pollution control in the Beijing-Tianjin-Hebei (BTH) region: Progress, challenges and opportunities. International Journal of Environmental Research and Public Health, 15(2), 2-27. doi:10.3390/ ijerph15020306

Wang, Z., Zhao, J., Li, F., Gao, D. \& Xing, B. (2009). Adsorption and inhibition of acetylcholinesterase by different nanoparticles. Chemosphere, 77(1), 66-73. doi:10.1016/j.chemosphere.2009.05.015 
